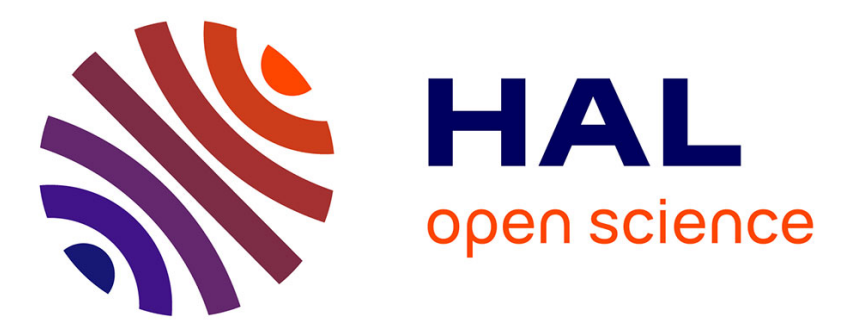

\title{
Leaf Nutrients and Macroinvertebrates Control Litter Mixing Effects on Decomposition in Temperate Streams
}

\author{
Mathieu Santonja, Hector Rodriguez-Perez, Nathalie Le Bris, Christophe
}

Piscart

\section{- To cite this version:}

Mathieu Santonja, Hector Rodriguez-Perez, Nathalie Le Bris, Christophe Piscart. Leaf Nutrients and Macroinvertebrates Control Litter Mixing Effects on Decomposition in Temperate Streams. Ecosystems, 2020, 23 (2), pp.400-416. 10.1007/s10021-019-00410-9 . hal-02165628

\section{HAL Id: hal-02165628 \\ https://hal-amu.archives-ouvertes.fr/hal-02165628}

Submitted on 9 Jul 2019

HAL is a multi-disciplinary open access archive for the deposit and dissemination of scientific research documents, whether they are published or not. The documents may come from teaching and research institutions in France or abroad, or from public or private research centers.
L'archive ouverte pluridisciplinaire HAL, est destinée au dépôt et à la diffusion de documents scientifiques de niveau recherche, publiés ou non, émanant des établissements d'enseignement et de recherche français ou étrangers, des laboratoires publics ou privés. 
1 TITLE: Leaf nutrients and macroinvertebrates control litter mixing effects on decomposition in

2 temperate streams

3

4 RUNNING HEAD: Litter mixture decomposition in temperate streams

5

6 Authors: Mathieu Santonja ${ }^{1,2 *}$, Héctor Rodríguez-Pérez ${ }^{1}$, Nathalie Le Bris ${ }^{1}$, Christophe 7 Piscart $^{1}$

8

9 ADDRESSES

10 1. Univ Rennes, CNRS, ECOBIO UMR 6553, F-35000 Rennes, France.

11 2. Aix Marseille Univ, Avignon Université, CNRS, IRD, IMBE, Marseille, France.

12

13 *CORRESPONDING AUTHOR

14 Email: mathieu.santonja@gmail.com

15 ORCID: 0000-0002-6322-6352

16 


\section{Abstract}

Plant litter decomposition is an essential ecosystem function in temperate streams. Both riparian vegetation and decomposer communities are major determinants of the decomposition efficiency and the interactions occurring within litter mixtures. However, the extent to which such litter mixture interactions are affected by combined shifts in litter traits and decomposer community is not well understood. We used leaf litter from 10 European tree species in order to study litter decomposition and litter mixture effects occurring in two-species litter mixtures in a temperate forested stream of northwestern France. The study distinguished between (i) decomposition involving microorganisms alone or together with invertebrates, and (ii) decomposition involving litter mixtures of similar or dissimilar nutrient content. Increasing mean litter nutrient concentration favored both microbial activity and litter decomposition rate. Surprisingly, the highest litter mixture effects occurred in mixtures containing two nutrient-rich litters and occurred mainly in macroinvertebrate presence. Both the "mass-ratio hypothesis", expressed as the community weighted mean traits (Trait ${ }_{\mathrm{CWM}}$ ), and the "niche complementarity hypothesis", expressed as the functional dissimilarity of litter traits (Trait ${ }_{\mathrm{FD}}$ ), contributed to explain litter mixture effects. However, Traitcwm was found to be a better predictor than TraitFD. Finally, when evaluating the individual contributions of litter nutrients, calcium and magnesium appeared as important drivers of litter mixture effects. Our findings suggest that the mass-ratio hypothesis overrules the niche complementarity hypothesis as a driver of litter diversity effects. Our study highlights the key importance of macroinvertebrates and of leaf nutrients, such as Ca and $\mathrm{Mg}$, which are often neglected in decomposition studies in streams.

KEYWORDS: Biodiversity-ecosystem functioning; community weighted means; functional trait dissimilarity; litter traits; litter decomposition; litter nutrients; temperate stream 


\section{HighLIGHTS}

42 - Macroinvertebrates and leaf nutrients drive microbial activity and litter decomposition

$43 \quad$ rate

44 - Macroinvertebrate presence and nutrient concentration control litter mixing effect $45 \quad$ intensity

46 - Mean nutrient concentration is more important than concentration dissimilarity within $47 \quad$ litter mixture 


\section{INTRODUCTION}

Litter decomposition is an essential ecosystem function controlling the carbon (C) and nutrient cycles in both terrestrial (Swift and others 1979; Cadish and Giller 1997) and aquatic (Cummins 1974; Wallace and others 1997) ecosystems. Litter decomposition rate is jointly affected by the litter traits (e.g. Cornwell and others 2008; Garcia-Palacios and others 2016), the environmental conditions, such as the temperature (e.g. Fierer and others 2005; Follstad Shah and others 2017), and the decomposer communities (e.g. Hättenschwiler and others 2015; Gessner and others 2010; Jabiol and others 2013; Santonja and others 2018a). Rates of litter decomposition are essentially controlled by litter chemistry (Cornwell and others 2008; GarciaPalacios and others 2016). In addition to secondary compounds (e.g. tannins) and fiber components (e.g. lignin), concentrations of nutrients such as nitrogen $(\mathrm{N})$ and phosphorus $(\mathrm{P})$ are useful litter traits for the prediction of the decomposition rates of single-species litter (Gessner and Chauvet 1994; Cornwell and others 2008; Schindler and Gessner 2009). Nevertheless, as mainly reported in terrestrial ecosystems, other nutrients such as calcium $(\mathrm{Ca})$, magnesium $(\mathrm{Mg})$, potassium $(\mathrm{K})$, sodium $(\mathrm{Na})$, and sulfur $(\mathrm{S})$, can also affect the decomposition efficiency (Kaspari and others 2008; Makkonen and others 2012; Garcia-Palacios and others 2016). However, the potential importance of these nutrients is often neglected in decomposition studies in streams compared to $\mathrm{N}$ and $\mathrm{P}$.

In the majority of natural ecosystems, litter material from different plant species decomposes together. Given that forested stream food webs are dependent upon allochthonous leaf litter (Vannote and others 1980; Wallace and others 1997; Gessner and others 1999), understanding the relationship between riparian tree species composition (and its associated litter traits) and the decomposition rates in streams draining forested watersheds is of considerable ecological importance (Swan and Palmer 2004; Kominoski and others 2007). Changing plant species composition can modify litter trait control over decomposition in two 
ways. First, according to the "mass-ratio hypothesis" (Grime 1998; Garnier and others 2004), litter trait control over decomposition changes along community-weighted mean (CWM) trait values (Fig. 1a, Quested and others 2007; Mokany and others 2008; Laughlin 2011). Second, according to the "niche complementarity hypothesis" (Petchey and Gaston 2006; Diaz and others 2007), a change in the functional dissimilarity (FD) of litter trait-values affects the degree to which resource-use complementary occurs within the decomposer community, and its capacity to induce non-additive litter mixing effects on decomposition (i.e. litter mixtures that decompose at different rates than predicted by the mass-ratio hypothesis) (Fig. 1b, Wardle and others 1997; Vos and others 2013; Handa and others 2014). These two mechanisms can operate simultaneously by affecting both decomposer community and decomposition efficiency as a result of plant (litter) composition change (e.g. Garcia-Palacios and others 2017; Santonja and others 2018b). However, our knowledge about the relative importance of these two mechanisms in controlling the decomposer communities and the efficiency of the decomposition process in streams is very limited.

Mechanisms involved in positive litter mixing effects likely include nutrient transfer, such as $\mathrm{N}$ or $\mathrm{P}$, from nutrient-rich to nutrient-poor litter species. For example, nutrients may be transported through fungal hyphae connecting two different leaf litter species (Schimel and Hättenschwiler 2007; Gessner and others 2010; Lummer and others 2012), in which case an acceleration of decomposition in species mixtures is expected since the nutrients are used more efficiently overall. According to the literature (Wardle and others 1997; Sanpera-Calbet et al. and others 2009; Santonja and others 2015a, 2015b; Santschi and others 2018), positive mixing effects are most likely expected in the mixtures including one poor-quality litter species and a high-quality one (Fig 1b; but see Frainer and others (2015) for contrasting results). However, whether, and to what extent, mixing litter affects decomposition rates in streams remains much debated, since litter mixture effects appear to be idiosyncratic (Schindler and Gessner 2009; 
100 highlighting contrasting results have focused on the effects of $\mathrm{N}$ and $\mathrm{P}$ in explaining such litter 101 mixture effects (e.g. Frainer and others 2015; Santschi and others 2018). However, other key

102 nutrients, such as $\mathrm{Mg}$ or $\mathrm{Ca}$, could potentially affect decomposition rates in litter mixtures. Additionally, it is also not clear to what extent macroinvertebrates contribute to

104 decomposition in litter mixtures (Hättenschwiler and Gasser 2005; Swan and Palmer 2006b;

105 Swan 2011). Shredder macroinvertebrates can play a prominent role in the decomposition process in stream ecosystems (Anderson and Sedell 1979; Cummins and Klug 1979; Handa and others 2014; Garcia-Palacios and others 2016), by consuming and fragmenting the litter material (Allan 1996; Graça 2001), by stimulating microbial decomposition (Wetzel 1995;

109 Villanueva and others 2012), and by mediating plant diversity effects on litter decomposition 110 (Lecerf and others 2005; Kominoski and others 2007; Sanpera-Calbet and others 2009). 111 According to Cummins and others (1989), such a role played by macroinvertebrates would be

112 higher in litter mixtures of distinct degradability than in more homogeneous litter mixtures. 113 Indeed, this type of litter mixture could simultaneously create a suitable microhabitat (more 114 refractory litter) and a food resource (more labile litter). Additionally, litter mixtures could 115 promote an increase in both growth rate (Swan and Palmer 2006a) and macroinvertebrate 116 population due to their aggregative behavior (Presa-Abós and others 2006), enhancing therefore 117 the decomposition of litter mixtures (Sanpera-Calbet and others 2009).

118 In order to address these gaps, we used leaf litter from 10 common European tree species 119 to evaluate how litter diversity effects are affected by litter nutrients $(\mathrm{Ca}, \mathrm{K}, \mathrm{Mg}, \mathrm{N}, \mathrm{Na}, \mathrm{P}$, and $120 \mathrm{~S}$ ) in a temperate stream. Moreover, in order to elucidate which organisms may be responsible 121 for mediating such litter diversity effects, we distinguished between decomposition involving microorganisms alone (with decomposition in fine-mesh litterbags) and both microorganisms

123 and macroinvertebrates (with decomposition in coarse-mesh litterbags) (Boulton and Boon 
124 1991). Five of the plant species showed nutrient-rich litter, while the other five showed nutrient-

125 poor litter (Fig. 2). Mixtures of two litter species were created in all possible pairwise 126 combinations, in order to distinguish between litter mixtures of similar nutrient content (i.e. in 127 mixing two nutrient-poor or two nutrient-rich litters) and litter mixtures of dissimilar nutrient 128 content (i.e. in mixing one nutrient-poor litter and one nutrient-rich litter). Despite the fact that 129 both litter traits, litter mass loss and microbial activity are continuous variables, such artificial 130 distinction into two discrete nutrient categories was necessary to better understand where and 131 why litter diversity effects occur. We evaluated (i) the litter decomposition rate and the 132 microbial activity (i.e. $\mathrm{CO}_{2}$ production) in the two-species litter mixtures, and (ii) the litter 133 diversity effects occurring on the decomposition rate and on the microbial activity in these litter 134 mixtures after 30 days of immersion in a temperate forested stream in northwestern France 135 (Piscart and others 2009).

136 First, according to the "mass-ratio hypothesis" (Grime 1998; Garnier and others 2004),

137 the increase in both litter decomposition rate and microbial activity would be positively 138 correlated to the increase in CWM scores in nutrient concentration within the litter mixture 139 (Cornwell and others 2008; Foucreau and others 2013). Therefore, in our first hypothesis, we 140 predicted higher litter decomposition rate and microbial activity in the mixture of two nutrient141 rich litters (Fig. 1a). Second, according to the "niche complementarity hypothesis" (Petchey 142 and Gaston 2006; Diaz and others 2007), mixtures of very dissimilar litter species yield the 143 highest FD scores and are related to higher litter diversity effects (Wardle and others 1997; 144 Lecerf and others 2011; Santschi and others 2018). Thus, in our second hypothesis, we 145 predicted the highest litter diversity effects in the mixtures of nutrient-poor and nutrient-rich 146 litters (Fig. 1b), which would be shown by an increase in litter decomposition rate and microbial 147 activity due to synergistic effects between the two litters in mixtures in the present study. 148 Finally, macroinvertebrates may contribute up to 6 times more influence than microorganisms 
on litter decomposition in temperate unaltered forested streams (Piscart and other 2009), favor

150 microbial community development (Wetzel 1995; Villanueva and others 2012), and mediate

151 litter diversity effects (Lecerf and others 2005), we hypothesized that litter decomposition rate,

152 microbial activity, and litter diversity effects would be enhanced by macroinvertebrate presence

153 (Figs. 1a and 1b).

MATERIALS AND METHODS

\section{Study site and material collection}

The experiment was conducted in the Hermitage stream, located in the Villecartier Forest in northwestern France $\left(48^{\circ} 28^{\prime} \mathrm{N}, 1^{\circ} 33^{\prime} \mathrm{W}\right)$. The stream bed was dominated by sand and leaf litter (site H1 in Piscart and others 2009). The stream water was circumneutral, welloxygenated, and possessed moderate nutrient concentrations (Piscart and others 2009): $11 \pm 1$ $\mathrm{mg} \mathrm{l}^{-1}$ dissolved oxygen, $49 \pm 18 \mu \mathrm{g} \mathrm{N}^{-1}$ ammonium, $510 \pm 19 \mu \mathrm{g} \mathrm{N} \mathrm{l}^{-1}$ nitrate, $10 \pm 8 \mu \mathrm{g} \mathrm{N}^{-}$ crustaceans representing 74\% of this macroinvertebrate community (Supplementary Table S1).

166 Fagus sylvatica was the dominant tree species in the forested watershed, but the riparian vegetation was composed of diverse deciduous tree species, including those employed in the experiment.

The leaf litter of 10 common European tree species was collected: Acer platanoides,

170 Alnus glutinosa, Betula pendula, Castanea sativa, Corylus avellana, Carpinus betulus, Fagus

171 sylvatica, Quercus robur, Salix atrocinerea and Tilia cordata, hereafter referred to by their

172 genus name. These 10 species were selected using the existing literature (e.g. Lecerf and others

173 2007; Schindler and Gessner 2009; Santonja and others 2018a), based on the nutrient 
concentrations of their leaves, to represent five species with nutrient-rich litter (NRL), and five

175 with nutrient-poor litter (NPL) (Fig. 2; a cluster analysis well discriminates these two groups).

176 Freshly abscised leaves were collected over the entire period of maximum litter fall, from

177 October to November 2015. They were dried at room temperature, and stored until the

178 beginning of the experiment.

179

180

\section{Litter decomposition experiment}

Leaf litter decomposition was studied for a period of 30 days, using the litterbag method

182

183

184

185

186

187

188

189

190

191

192

193

194

195 or three disks for each species in the two-species litter mixtures, were cut for the purpose of (Boulton and Boon 1991). Coarse- and fine-mesh litterbags (5 mm and $0.5 \mathrm{~mm}$ mesh size, respectively) were used and filled with $2 \mathrm{~g}$ of dry leaves. The leaf litter enclosed in fine-mesh litterbags was only accessible to microorganisms, whereas the coarse-mesh bags also allowed access to macroinvertebrates. The litterbags contained either a single species (10 treatments) or a mixture of two species in all possible pairwise combinations (45 treatments). The mixedspecies litterbags received equal amounts of both species (i.e. $1 \mathrm{~g})$. A total of 440 litterbags ([10 single-species +45 two-species mixtures] $\times 2$ mesh sizes $\times 4$ replicates) were used for the experiment.

In December 2016, the litterbags were immersed for 30 days in the Hermitage stream. After removal, the litterbags were immediately sealed in plastic bags to prevent the loss of litter material and were transported to the laboratory. The leaves were separated by species, which was possible even with small fragments of litter (owing to marked morphological differences among the species) and were carefully cleaned under water to remove macroinvertebrates and attached sediment particles.

Avoiding the central veins, six leaf discs (10 mm-diameter) for the single-species litters,

198 microbial activity measurement. The remaining leaf material was frozen at $-20^{\circ} \mathrm{C}$. 
Microbial activity measurement

Microbial $\mathrm{CO}_{2}$ production measurements, as a measure of overall heterotrophic

microbial activity, were performed in order to evaluate the activity of the microbial communities that colonized the leaves after 30 days of decomposition. We adapted the protocol proposed by Anderson and Domsch (1973). Briefly, the six leaf disks taken in each litterbag were placed in $125 \mathrm{ml}$ glass bottles with $25 \mathrm{ml}$ of filtered water (GF/F glass microfiber filter, Whatman ${ }^{\mathrm{TM}}$ ) from the Hermitage stream and then preincubated for $12 \mathrm{~h}$ at $20{ }^{\circ} \mathrm{C}$ in the dark allowing the microbial respiration to saturate the water with $\mathrm{CO}_{2}$. In the matter of fact, at constant temperature, it is only possible to increase the $\mathrm{CO}_{2}$ concentration in the air phase of the respiration chamber if the aqueous phase is oversaturated in $\mathrm{CO}_{2}$. After a night of remaining open to the atmosphere, the respiration chambers were hermetically sealed and the first sample of air was taken, the second air sample was sampled after a $4 \mathrm{~h}$ incubation at $20{ }^{\circ} \mathrm{C}$ in the dark. $\mathrm{CO}_{2}$ production in a given time (i.e. $4 \mathrm{~h}$ ) was then calculated as the difference between the final $\mathrm{CO}_{2}$ concentration and the initial $\mathrm{CO}_{2}$ concentration. Preliminary studies with our experimental

214 conditions demonstrated that the $\mathrm{CO}_{2}$ production was linear and, since all the process of 215 incubation occurred in the dark, there was no photosynthesis and thus no alteration of the 216 dissolved $\mathrm{CO}_{2}$ partial pressure. In total, 440 respiration chambers, corresponding to the 440 217 litterbags, were prepared. At the beginning and at the end of the incubation period, $1 \mathrm{ml}$ of air, 218 taken with a syringe, was injected into a gas chromatograph ( $\mu$ GC SRA A 3000) in order to 219 estimate the microbial activity (i.e. $\mathrm{CO}_{2}$ air content). The leaf discs were then dried at $65{ }^{\circ} \mathrm{C}$ for $22072 \mathrm{~h}$ and the $\mathrm{CO}_{2}$ production was calculated as $\mu \mathrm{g} \mathrm{C}-\mathrm{CO}_{2}$ per $\mathrm{h}$ and per $\mathrm{g}$ of litter dry mass $( \pm$ $2210.1 \mathrm{mg})$. 
the leaf disks and remaining leaf litter, all the litter material from a given litterbag was combined

225 and ground to a fine powder using a ball mill, before measuring the litter ash content. We

226 obtained ash-free dry mass by burning the combined sample at $550{ }^{\circ} \mathrm{C}$ for $4 \mathrm{~h}$. Additional

227 samples were also used to estimate ash-free dry mass of the initial litter material. The percentage

228 of ash-free dry mass data was used to correct both the initial and the remaining leaf material

229 before the computation of (i) the percentage of litter mass loss after 30 days of field 230 decomposition and (ii) the microbial $\mathrm{CO}_{2}$ production per $\mathrm{h}$ and per $\mathrm{g}$ of litter.

\section{Litter trait measurement}

The initial litter traits were determined from four samples of each of the 10 litter species

234 (Supplementary Table S2). Prior to the chemical analysis, each litter sample was ground into 235 powder using a ball mill. The carbon $(\mathrm{C})$, nitrogen $(\mathrm{N})$, and sulfur $(\mathrm{S})$ concentrations were determined by thermal combustion, using a Vario Pyro cube CNS analyzer (Elementar France SARL, Lyon, France). The phosphorus (P) concentration was measured colorimetrically using 238 the molybdenum blue method (Grimshaw and others 1989). To $80 \mathrm{mg}$ of ground litter sample $2398 \mathrm{ml}$ of $\mathrm{HNO}_{3}$ and $2 \mathrm{ml}$ of $\mathrm{H}_{2} \mathrm{O}_{2}$ were added and the mixture was heated at $175{ }^{\circ} \mathrm{C}$ for $40 \mathrm{~min}$ 240 using microwaves (Ethos One, Milestone SRL, Italy). After this mineralization step, the sample 241 was diluted to a total of $50 \mathrm{ml}$. A hundred $\mu \mathrm{l}$ of sample, $100 \mu \mathrm{l}$ of $\mathrm{NaOH}, 50 \mu 1$ of mixed reagent 242 (emetic tartar and ammonium molybdate solution), and $50 \mu 1$ of ascorbic acid were mixed 243 directly in a 96 well microplate. After $30 \mathrm{~min}$ at $40{ }^{\circ} \mathrm{C}$, the reaction was completed, and the $\mathrm{P}$ 244 concentration was measured at $720 \mathrm{~nm}$ using a microplate reader (Victor, PerkinElmer, 245 Singapore). Following the mineralization step (i.e. the same as for P analysis), calcium (Ca), magnesium $(\mathrm{Mg})$, potassium $(\mathrm{K})$, and sodium $(\mathrm{Na})$ concentrations were measured using an

247 atomic absorption spectrometer (AAS, iCE 3000 series, ThermoScientific, China). 
To assess the "mass-ratio hypothesis", we calculated the community-weighted mean

249 (CWM) trait values of litter mixtures as the average trait values of litter mixtures following

Garnier and others (2004) as: Trait $_{\mathrm{CWM}}=\sum_{i=1}^{n} p_{i} \times$ trait $_{i}$, where $p_{i}$ is the relative abundance

for species $i$ in the litter mixture and trait $_{i}$ is the trait value for species $i$. These calculations were performed for each of the 8 litter traits. The highest scores of CWM were reached for litter mixtures containing two litter species with the highest nutrient concentrations (Fig. 1a). Since we predicted that both microbial activity and litter decomposition rate respond to the "massratio hypothesis", we expected the increase in both decomposition rate and microbial activity to be positively correlated to the increase in CWM values.

To assess the "niche complementarity hypothesis", we calculated the functional dissimilarity (FD) of litter mixtures according to Rao's quadratic entropy (Botta Dukat 2005; Epps and others 2007) as: Trait $\mathrm{FD}_{\mathrm{FD}}=\sum_{\mathrm{i}=1}^{\mathrm{n}} \sum_{\mathrm{j}=1}^{\mathrm{n}}$ pipj $* d i j$, where $p_{i}$ and $p_{j}$ are the relative abundance for species $i$ and $j$ in the litter mixture, and $d_{i j}$ the Euclidian distance between species $i$ and $j$ for the trait considered. These calculations were performed for each of the 8 litter traits. The highest scores of FD were reached for litter mixtures containing two species with very dissimilar nutrient concentrations (Fig. 1b). Since we predicted that the litter diversity effects respond to the "niche complementarity hypothesis", we expected the increase in relative litter mixture effects to be positively correlated to the increase in FD values.

\section{Statistical analyses}

All of the statistical analyses were conducted using R software (R Core Team 2013), with significance levels indicated as * for $P<0.05, * *$ for $P<0.01$, and $* * *$ for $P<0.001$.

A principal component analysis (PCA) was conducted using the values of the eight 271 measured litter traits of the 10 tree species (Supplementary Table S2) in order to discriminate 272 the five tree species with nutrient-rich litter (NRL) from the other five tree species with nutrient- 
273 poor litter (NPL). The differences in the initial litter traits were assessed using one-way

274 ANOVAs, followed by Tukey's tests to carry out post-hoc pairwise comparisons. For the single-species litter, three-way ANOVAs, followed by Tukey's post hoc tests, 276 were used to test for the effects of litter type (separated in NPL vs. NRL), litter species identity 277 (10 litters), macroinvertebrate presence (fine-mesh bag [FMB] vs. coarse-mesh bag [CMB]), 278 and their interactions on litter decomposition rate and microbial activity. In order to further test whether litter decomposition and microbial activity differed between litter mixtures and single litter species, the relative litter mixture effects (RME) on litter decomposition rate and microbial activity were calculated. The RME was calculated as the relative difference between the observed litter decomposition rate/microbial activity $(\mathrm{O})$ from the litter mixtures compared to those expected based on the respective single litter species treatments $(\mathrm{E})$, following the formula $(\mathrm{O}-\mathrm{E}) / \mathrm{E} \times 100 \%$ (Wardle and others 1997). Onesample Student's $t$-tests were used to test whether the RME were significantly different from zero.

For the two-species litter mixtures, two-way ANOVAs, followed by Tukey's post hoc tests, were used to test for the effects of litter mixing (NPL-NPL, NPL-NRL and NRL-NRL), macroinvertebrate presence (FMB vs. $\mathrm{CMB}$ ), and their interactions i) on litter decomposition rate and microbial activity and ii) on the RME on litter decomposition rate and on microbial activity.

For a more detailed understanding of how the mixture of leaf litter affected the litter 293 decomposition rate and microbial activity, we evaluated the effects of the mean litter traits 294 (Trait ${ }_{\mathrm{CWM}}$ ) and functional litter trait dissimilarities (Trait ${ }_{\mathrm{FD}}$ ) of the eight measured litter traits 295 (Supplementary Table S2). First, a principal component analysis (PCA) was conducted using the CWM or the FD values of the eight measured litter traits across the 45 two-species litter mixtures. CWM1 and CWM2, and FD1 and FD2 represented the two first components of the 
PCAs conducted using the CWM or the FD values across the litter mixtures, respectively.

299 Second, multiple linear regression models were performed in order to decipher the relative contributions of Trait ${ }_{C W M}$ and Trait $t_{F D}$. In these models the effects of the Traits CWM $_{\text {(i.e. CWM1 }}$ and CWM2), TraitsFD (i.e. FD1 and FD2), macroinvertebrate presence (FMB vs. CMB), and their interactions were tested i) on litter decomposition rate and microbial activity and ii) on the RME on litter decomposition rate and on microbial activity.

RESUlTS

\section{Litter traits}

The PCA based on the element concentrations showed that the first PCA axis explained $50.2 \%$ of the variation and discriminated between the nutrient-rich litters (NRL) on the left and the nutrient-poor litters (NPL) on the right of the axis (Fig. 2).

\section{Litter species incubated individually}

The NRL exhibited two times more litter mass loss and microbial activity than the NPL

314 (Table 1; Fig. 3). The presence of macroinvertebrates increased the litter mass loss and the microbial activity, but this effect was dependent on the litter type (litter type $\times$ mesh size interaction, Table 1). This significant interaction was explained by a stronger increase in litter mass loss and microbial activity in the NRL category $(+59 \%$ litter mass loss and $+33 \%$

318 microbial activity) compared to the NPL category ( $+23 \%$ litter mass loss and $+28 \%$ microbial 319 activity) (Fig. 3). In addition, litter mass loss and microbial activity were significantly affected by litter species identity (Table 1). Within the NRL category, Alnus showed the highest litter mass loss compared to the four other species (Supplementary Fig. S1a), as well as a higher microbial 
activity than Carpinus, Acer, and Tilia (Supplementary Fig. S1b). Within the NPL category,

324 Salix and Betula showed both a higher litter mass loss and a higher microbial activity than the 325 three other species (Supplementary Fig. S1a and S1b). The positive effect of the

326 macroinvertebrate presence on the litter mass loss also varied according to the litter species 327 identity (litter species $\times$ mesh size interaction, Table 1), as the effects ranged from $+68 \%$ for 328 Alnus to an absence of effect for Fagus (Supplementary Fig. S1a).

\section{Effects of mixing low- and high-quality litter}

Litter mass loss and microbial activity increased according to the gradient NPL-NPL < NPL-NRL < NRL-NRL mixtures (Table 2; Fig. 4a and 4c), with two times more litter mass loss and microbial activity in mixtures of two nutrient-rich litters compared to the mixtures of two nutrient-poor litters. The relative mixture effects (RME) on litter mass loss and on microbial activity showed a similar trend, with an increase in RME according to the same gradient (Table 2; Fig. 5). The NPL-NPL mixtures lost $-3.5 \%$ litter mass compared with the expected values from the respective single litter species (Fig. 5a), while the observed microbial activity of the NPL-NPL mixtures did not differ significantly from the expected values (Fig. 5c). The NPL-NRL mixtures lost $+5.3 \%$ litter mass than expected from the respective single litter species (Fig. 5a), while the observed microbial activity of the NPL-NRL mixtures did not differ from the expected values (Fig. 5c). The NRL-NRL mixtures showed $+8.9 \%$ litter mass and $+16.3 \%$ microbial activity than expected from the respective single litter species (Figs. 5a 343 and $5 c)$.

Litter mass loss and microbial activity were respectively $41 \%$ and $30 \%$ higher with macroinvertebrates than without (Table 2; Fig. 4b and 4d). The RME on litter mass loss and on

346 microbial activity were also higher with macroinvertebrates than without (Table 2). 347 Specifically, the litter mixtures exhibited synergistic effects in the presence of 
macroinvertebrates, with $+7.3 \%$ litter mass loss and $+9.9 \%$ microbial activity than expected

349 from the respective single litter species (Figs. 5b and 5d).

\section{CWM- versus FD-trait control over litter decomposition rate and microbial activity}

The PCA of the CWM traits showed that the first PCA axis (CWM1), explaining 50.2\% of the variation, was determined by high scores of $\mathrm{P}$ and $\mathrm{Ca}$ concentrations, and, to a lower extent, by the scores of the $\mathrm{K}, \mathrm{Mg}, \mathrm{Na}$, and $\mathrm{S}$ concentrations (Supplementary Fig. S2a). The low scores of the second PCA axis (CWM2), explaining $21.9 \%$ of the variation, were related to high values of $\mathrm{N}$ and $\mathrm{C}$ concentrations (Supplementary Fig. S2a). Regarding functional trait dissimilarity, high scores of the first PCA axis (FD1), explaining 28.5\% of the variation, were related to the increase in dissimilarity in the $\mathrm{Mg}, \mathrm{S}$, and $\mathrm{C}$ concentrations, while the low scores were related to the increase in dissimilarity in the $\mathrm{N}$ and Ca concentrations (Supplementary Fig. $\mathrm{S} 2 \mathrm{~b}$ ). The low scores along the second axis (FD2), explaining $22.0 \%$ of the variation, were largely dependent on the increase in dissimilarity in the $\mathrm{K}, \mathrm{Na}$, and $\mathrm{P}$ concentrations (Supplementary Fig. S2b).

When simultaneously evaluating the effects of the CWM and FD traits (Table 3), we found that both litter mass loss and microbial activity were mainly controlled by the CWM values (i.e. increasing mean nutrient concentrations within the litter mixture) compared to the FD values (i.e. increasing dissimilarity in nutrient concentrations within the litter mixture). In fact, CWM values (CWM1 + CWM2) explained respectively 9 and 15 times more of the overall variance in litter mass loss and in microbial activity than FD values (FD1 + FD2) (Table 3).

When simultaneously evaluating the effects of the CWM and FD traits on RME, we found that the RME on litter mass loss was controlled by the CWM (CWM1), the presence of macroinvertebrates, and the interaction between the FD and the presence of macroinvertebrates $($ FD2 $\times$ mesh size) (Table 3). Increasing CWM1 scores was related to higher RME (Fig. 6a). 
373 The significant interaction between FD2 and mesh size (Table 3) showed that increasing FD in

374 the initial K, Na, and P concentrations stimulated microbial-driven RME (Fig. 6d). Concerning 375 the RME on microbial activity, it was found to be significantly affected only by CWM1 and the 376 presence of macroinvertebrates (Table 3). Similar to what we observed for litter mass loss, 377 increasing CWM1 scores was related to higher RME on microbial activity (Fig. 6e).

378 The RME on litter mass loss appeared to be more strongly correlated with the increase

379 in $\mathrm{P}, \mathrm{Ca}, \mathrm{Mg}$ and $\mathrm{Na}$ concentrations than with the $\mathrm{K}, \mathrm{N}$, or $\mathrm{S}$ concentrations, and these 380 relationships were more marked in the coarse-mesh litterbags in which macroinvertebrates were 381 present, than in the fine-mesh litterbags in which macroinvertebrates were absent (Table 4). 382 The RME on microbial activity appeared to be more strongly correlated with the increase in $383 \mathrm{Ca}, \mathrm{K}$, and $\mathrm{Mg}$ concentrations than in $\mathrm{N}$ and $\mathrm{P}$ concentrations, and these relationships were also more marked in the presence than in the absence of macroinvertebrates (Table 4).

\section{DISCUSSION}

Niche complementarity hypothesis vs. mass-ratio hypothesis for explaining litter diversity effects

We found evidence of leaf litter diversity effects on decomposition rates, including 391 additive, synergistic, and antagonistic effects, as previously shown in other studies (Kominoski and others 2007; Srivastava and others 2009; Lecerf and others 2011; Handa and others 2014).

393 Surprisingly, the pattern observed in our study highlighted that the largest mixture effects 394 occurred in mixtures containing the combination of two nutrient-rich litters (NRLs), rather than in mixtures of one nutrient-rich litter (NRL) and one nutrient-poor litter (NPL), as predicted in our second hypothesis (Fig. 1b). Such a finding is in agreement with the mass-ratio hypothesis, and emphasizes the fact that increasing the mean value of the nutrient pool in litter mixtures 
favors the occurrence of litter diversity effects. In any case our results pointed out that the litter

399 diversity effects on decomposition were strongly litter-quality dependent. This finding is congruent with the recent study of Jabiol and Chauvet (2015) in which higher synergistic effects on litter decomposition occurred when Alnus glutinosa was combined with Fraxinus angustifolia (i.e. two NRLs) than when Alnus glutinosa was combined with Quercus ilex (i.e. one NRL and one NPL).

Surprisingly, Trait ${ }_{\mathrm{CWM}}$ proved to be a better predictor of litter diversity effects than Trait FD, for both the coarse- and fine-mesh litterbags, contrasting with our second hypothesis. Indeed, based on the well-developed literature on the drivers of the litter decomposition process (e.g. Hättenschwiler and others 2005; Cornwell and others 2008; Gessner and others 2010; Makkonen and others 2012; Vos and others 2013; Handa and others 2014; Garcia-Palacios and others 2017), we expected that litter diversity effects occur when there are increases in the nutrient concentration dissimilarity of the litter mixtures (i.e. according to the niche complementary hypothesis, Fig. 1b), while the mean nutrient concentration within the litter mixture must only explain the litter decomposition rate (i.e. according to the mass-ratio hypothesis, Fig. 1a). The results from the coarse-mesh litterbags showed no evidence of nutrient 414 dissimilarity effect (Trait ${ }_{\mathrm{FD}}$ ), conforming with the conclusion of Frainer and others (2015), which also highlighted, over a lower range of litter traits (N, P, and lignin), that no litter 416 dissimilarity effect was involved in the litter diversity effects occurring in two-species mixtures. 417 In contrast, Trait $\mathrm{FD}$ was linked to the litter diversity effects for the fine-mesh litterbags. In this 418 case, litter mixtures with contrasting nutrient concentrations may have improved the availability 419 of different nutrient sources for microorganisms (Schimel and Hättenschwiler 2007; Handa and 420 others 2014), as suggested by the niche complementarity hypothesis. Filamentous fungi, 421 including the aquatic hyphomycetes that dominate fungal communities on decomposing leaves in streams (Krauss and others 2011), can indeed extend their hyphae over considerable distances 
in order to acquire remote resources that they transport to the locations of active hyphal growth

424 (Ritz 2006). It has previously been suggested that fungi-driven $\mathrm{N}$ transfer among litter species varying in their initial $\mathrm{N}$ concentration may contribute to litter mixture effects (Schimel and Hättenschwiler 2007; Vos and others 2013; Handa and others 2014). Thus, nutrients from a nutrient-rich litter may be translocated to another litter depleted in nutrient (i.e. a nutrient-poor 428 litter; Schimel and Hattenschwiler 2007; Handa and others 2014). Therefore, our findings 429 highlighted that both Trait ${ }_{\mathrm{CWM}}$ and Trait $_{\mathrm{FD}}$ contributed to explain litter diversity effects driven 430 by microorganisms alone. Interestingly, Trait $\mathrm{FD}$ did not explain litter diversity effects driven by 431 microorganisms and macroinvertebrates together. In this case, it could be hypothesized that the 432 additional nutrients provided by macroinvertebrate feces alleviated the nutrient limitation for 433 microorganisms (Wetzel 1995; Joyce and Wotton 2008), and consequently the Trait 434 contribution to litter diversity effects.

\section{Macroinvertebrates control over decomposition and litter diversity effects}

Across all of the 45 litter mixtures, litter mixture decomposition was not found to be enhanced in the fine-mesh litterbags (i.e. additive effects), while the litter mixtures in the coarse-mesh litterbags lost on average $7.3 \%$ more mass than the litter in the single-species treatments (i.e. synergistic effects). The absence of litter mixture effects when macroinvertebrates were excluded suggests that the activity of microbial decomposers alone

442 did not induce any effect of litter mixture on decomposition in the studied temperate stream. 443 Previous studies performed in lotic systems, where decomposition primarily involves 444 microorganisms, have also reported a lack of a synergism (Ferreira and others 2012; Bruder 445 and others 2014). For instance, similar to our findings, Jabiol and Chauvet (2015) reported that 446 no effect of litter mixture was observed when detritivores were excluded during the litter 447 decomposition in a Mediterranean stream in southern France. In a laboratory experiment, Swan 
and Palmer (2006b) also reported that litter mixture effects were contingent on the feeding activity of the isopod Caecidotea communis.

In homogenous species mixtures comprising litters of a single litter category,

macroinvertebrates have little choice to select among different qualities of leaves, as opposed

to the choice offered between leaf litter species in heterogeneous litter mixtures (Swan and Palmer 2006b). However, as macroinvertebrates can simultaneously exploit multiple litter species to meet their elemental demands (Leroy and Marks 2006), combining two NRLs that nutritionally complement one another might stimulate the feeding activity of detritivores (Vos and others 2013). For example, the mixing of one P-rich with one N-rich species in the present the mixture by $14 \%$, probably due to the increased nutritional value of such litter mixing. In contrast, mixing two P-rich species (e.g. Acer platanoides and Carpinus betulus) increased litter mass loss of the mixture by only $4 \%$, while mixing two P-poor species (e.g. Castanea sativa and Fagus sylvatica) decreased litter mass loss of the mixture by $10 \%$. Alternatively in

NRL+NPL mixtures, high detritivore density may be promoted by the co-occurrence of a suitable resource, such as that provided by the nutrient-rich litter, and a complex and structured habitat provided by the nutrient-poor litter (Sanpera-Calbet and others 2009; Jabiol and others 2014).

\section{Litter nutrients control over decomposition and litter diversity effects}

In agreement with our predictions and the literature, nutrient-rich litters decomposed faster than nutrient-poor litters, confirming that nutrient concentration is an important determinant of leaf litter decomposition (Kaspari and others 2008; Makkonen and others 2012;

471 Garcia-Palacios and others 2016). The rates of litter decomposition observed in the present 472 study were similar to those reported in other studies concerning temperate streams (e.g. Lecerf 
474 and others (2007) reported $80 \%$ and $42 \%$ mass loss for Alnus glutinosa (i.e. a nutrient-rich 475 litter) and Quercus robur (i.e. a nutrient-poor litter), respectively, after 34 days of 476 decomposition in a temperate stream in central France. The results of the present study were 477 also similar to the $16.5 \%$ mass loss for Fagus sylvatica (i.e. a nutrient-poor litter) after 30 days 478 of decomposition obtained in the same Petit Hermitage stream in February 2005 (Piscart and 479 others 2009).

Moreover, our results also highlighted the important role of nutrients not usually considered in litter diversity experiments. The first principal component of the CWM-trait PCA was the main driver of litter diversity effects in both fine- and coarse-mesh litterbags, and was driven by $\mathrm{P}, \mathrm{Ca}, \mathrm{K}, \mathrm{Mg}, \mathrm{Na}$, and $\mathrm{S}$. Their relative content in the leaves is closely related to one 484 other (Garcia-Palacios and others 2016), hampering a straightforward interpretation of combination of elements. Nevertheless, when evaluating the individual contributions of litter nutrients, $\mathrm{Ca}$ and $\mathrm{Mg}$ appeared to be important drivers of litter diversity effects compared to $\mathrm{N}$ (and to $\mathrm{P}$ only for microbial activity), suggesting for the first time that these two nutrients may play an important role in litter diversity effects in addition to, or independently of, the $\mathrm{P}$ or $\mathrm{N}$ 489 content. The $\mathrm{Ca}$ content is known to positively affect the growth and activity of aquatic hyphomycetes, by enhancing the fungal capacity to transfer $\mathrm{N}$ between distinct litter types (Jenkins and Suberkropp 1995). Meanwhile, Ca and Mg are known to be essential elements in 492 the diet of macroinvertebrates, since they are required for enzymatic reactions, nerve 493 connections, muscle function, and skeleton formation (National Research Council 2005). 494 Moreover, in some temperate streams, crustaceans could represent up to $95 \%$ of shredder biomass (Piscart and others 2011), and the Ca content of leaves could be a significant source of

496 Ca for their cuticles (Cairns and Yan 2009), especially in streams with a low Ca content in the 497 water (Glazier 1998), such as in Brittany, where the present study was conducted. 


\section{CONCLUSION}

As expected, increasing mean nutrient concentration and macroinvertebrate presence

501 favored both microbial activity and litter decomposition rate. In addition, we experimentally 502 demonstrated for the first time that the mass-ratio hypothesis (i.e. Trait ${ }_{\text {Cwm }}$ ) overrules the niche 503 complementarity hypothesis (Trait ${ }_{\mathrm{FD}}$ ) as a driver of litter diversity effects in a temperate stream.

504 In fact, in strong contrast to our expectations, the combination of two nutrient-rich litters yielded 505 the highest litter mixture effects. In addition, the synergistic effects of litter mixing were mainly 506 evident in the presence of macroinvertebrates. Both community weighted mean traits 507 (Trait ${ }_{\mathrm{CWM}}$ ) and the functional dissimilarity of litter traits (Trait $\mathrm{FD}_{\text {) }}$ contributed to explain the 508 litter mixture effects. There was no support for Trait $\mathrm{FD}$ explaining litter diversity effects in the 509 presence of macroinvertebrates, while both Trait ${ }_{C W M}$ and Trait ${ }_{\mathrm{FD}}$ contributed to explain litter mixture effects driven by microorganisms alone. Finally, $\mathrm{Ca}$ and $\mathrm{Mg}$, which are often neglected in decomposition studies in streams, were found to be important drivers of litter mixture effects.

\section{ACKNOWLEDGMENTS}

The chemical analyses were performed at the Plateforme d'Analyses Chimiques en 515 Ecologie (PACE, LabEx Centre Méditerranéen de l'Environnement et de la Biodiversité, 516 Montpellier, France), as well as at the PLateforme AnalYtique (PLAY, UMR CNRS 6553 517 ECOBIO, Rennes, France). We thank Raphaëlle Leclerc, Bruno Buatois and Nicolas Barthes 518 for technical assistance during the chemical analyses as well as Pierre Mariotte for his reviewing 519 of the English. This study was funded by the Selune project (project number 1053864 ) and by 520 the Rennes Metropole's project AIS 2015. The study was also supported by the LTSER France 521 Zone Atelier Armorique. Finally, the authors declare no conflict of interest. 


\section{AUTHORS' CONTRIBUTIONS}

M.S., H.R.P., N.L.B. and C.P. conceived and performed the experiments. M.S. analyzed the data and led the writing of the manuscript. All authors contributed critically to the drafts and gave final approval for publication.

\section{REFERENCES}

Allan DJ. 1996. Stream Ecology. Chapman and Hall, New York.

Anderson, JPE, Domsch KH. 1973. Quantification of bacterial and fungal contributions to soil respiration. Archiv für Mikrobiologie 93:113-127. Doi: 10.1007/BF00424942

Anderson NH, Sedell JR. 1979. Detritus processing by macroinvertebrates in stream ecosystems. Annual Review of Entomology 24:351-377. Doi: 10.1146/annurev.en.24.010179.002031

Botta Dukát Z. 2005. Rao's quadratic entropy as a measure of functional diversity based on multiple traits. Journal of Vegetation Science 16:533-540. Doi: 10.1658/11009233(2005)16[533:RQEAAM]2.0.CO;2

Boulton AJ, Boon PI. 1991. A review of methodology used to measure leaf litter decomposition in lotic environments: time to turn over an old leaf? Australian Journal of Marine Freshwater Resources 42:1-43. Doi: 10.1071/MF9910001

Bruder A, Schindler MH, Moretti MS, Gessner MO. 2014. Litter decomposition in a temperate and a tropical stream: the effects of species mixing, litter quality and shredders. Freshwater Biology 59:438-449. https://doi.org/10.1111/fwb.12276

Cadish G, Giller KE. 1997. Driven by Nature: Plant Litter Quality and Decomposition. CAB international, Wallingford. 
546 Cairns A, Yan N. 2009. A review of the influence of low ambient calcium concentrations on 547 freshwater daphniids, gammarids, and crayfish. Environmental Reviews 17:67-79. Doi: $548 \quad 10.1139 / \mathrm{A} 09-005$

549 Cardinale BJ, Matulich KL, Hooper DU, Byrnes JE, Duffy E, Gamfeldt L, ... Gonzalez A. 550 2011. The functional role of producer diversity in ecosystems. American Journal of Botany 551 98:572-592. Doi: 10.3732/ajb.1000364

552 Cornwell WK, Cornelissen JH, Amatangelo K, Dorrepaal E, Eviner VT, Godoy O, ... Westoby 553 M. 2008. Plant species traits are the predominant control on litter decomposition rates within

Cummins KW, Klug MJ. 1979. Feeding ecology of stream invertebrates. Annual review of ecology and systematics 10:147-172. Doi: 10.1146/annurev.es.10.110179.001051

Cummins KW, Wilzbach MA, Gates DM, Perry JB, Taliferro WB. 1989. Shredders and riparian 558 vegetation: Leaf litter that falls into streams influences communities of stream invertebrates.

\section{0} BioSciences 39:24-30 Doi: 10.2307/1310804

Cummins KW. 2012. Structure and function of stream ecosystems. Bioscience 24:631-641. https://doi.org/10.2307/1296676

Diaz S, Lavorel S, De Bello F, Quetier F, Grigulis K, Robson TM. 2007. Incorporating plant 563 functional diversity effects in ecosystem service assessments. Proceedings of the National 564 Academy of Sciences of the USA 104:20684-20689. Doi: 10.1073/pnas.0704716104

565 Epps KY, Comerford NB, Reeves III JB, Cropper Jr WP, Araujo QR. 2007. Chemical diversity566 highlighting a species richness and ecosystem function disconnect. Oikos 116:1831-1840. 567 568 Ferreira V, Encalada AC, Graça MA. 2012. Effects of litter diversity on decomposition and 569 biological colonization of submerged litter in temperate and tropical streams. Freshwater $570 \quad$ Science 31:945-962. Doi: 10.1899/11-062.1 
571 Fierer N, Craine JM, McLauchlan K, Schimel JP. 2005. Litter quality and the temperature 572 sensitivity of decomposition. Ecology 86:320-326. Doi: 10.1890/04-1254

573 Follstad Shah JJ, Kominoski JS, Ardón M, Dodds WK, Gessner MO, Griffiths NA, ... Manning 574 DW. 2017. Global synthesis of the temperature sensitivity of leaf litter breakdown in streams and rivers. Global Change Biology 23:3064-3075. Doi: 10.1111/gcb.13609

576 Foucreau N, Puijalon S, Hervant F, Piscart C. 2013. Effect of leaf litter characteristics on leaf 577 conditioning and on consumption by Gammarus pulex. Freshwater Biology 58:1672-1681. Doi: 10.1111/fwb.12158

Frainer A, Moretti MS, Xu W, Gessner MO. 2015. No evidence for leaf-trait dissimilarity effects on litter decomposition, fungal decomposers, and nutrient dynamics. Ecology 96:550-561. Doi: 10.1890/14-1151.1

Garcia-Palacios P, McKie BG, Handa IT, Frainer A, Hättenschwiler S. 2016. The importance of litter traits and decomposers for litter decomposition: a comparison of aquatic and terrestrial ecosystems within and across biomes. Functional Ecology 30:819-829. Doi: $10.1111 / 1365-2435.12589$

Garcia-Palacios P, Shaw EA, Wall DH, Hättenschwiler S. 2017. Contrasting mass-ratio vs. niche complementarity effects on litter $\mathrm{C}$ and $\mathrm{N}$ loss during decomposition along a regional climatic gradient. Journal of Ecology 105:968-978. Doi: 10.1111/j.1466-8238.2011.00651.x

Garnier E, Cortez J, Billès G, Navas ML, Roumet C, Debussche M, ... Toussaint JP. 2004. Plant functional markers capture ecosystem properties during secondary succession. Ecology 85:2630-2637. Doi: 10.1890/03-0799

Gessner MO, Chauvet E. 1994. Importance of stream microfungi in controlling breakdown rates of leaf litter. Ecology 75:1807-1817. Doi: 10.2307/1939639

Gessner MO, Chauvet E, Dobson M. 1999. A perspective on leaf litter breakdown in streams. Oikos 85:377-384. Doi: 10.2307/3546505 
596 Gessner MO, Swan CM, Dang CK, Mckie BG, Bardgett RD, Wall DH, Hättenschwiler S. 2010.

597 Diversity meets decomposition. Trends in Ecology and Evolution 25:372-380. Doi:

$598 \quad$ 10.1016/j.tree.2010.01.010

599 Glazier DS. 1998. Springs as model systems for ecology and evolutionary biology: a case study 600 of Gammarus minus Say (Amphipoda) in mid-Appalachian springs differing in $\mathrm{pH}$ and ionic 601 content. In: Botosaneanu L (eds) Studies in crenobiology: the biology of springs and 602 springbrooks, Backhuys Publishers, Leiden, pp 41-54.

603 Graça MAS. 2001. The role of invertebrates on leaf litter decomposition in streams-a review.

604 International Review of Hydrobiology 86:383-393. Doi: 10.1002/1522$605 \quad 2632(200107) 86: 4 / 5<383::$ AID-IROH383>3.0.CO;2-D

606 Grime JP. 1998. Benefits of plant diversity to ecosystems: immediate, filter and founder effects. 607 Journal of Ecology 86:902-910. Doi: 10.1046/j.1365-2745.1998.00306.x

608 Grimshaw HM, Allen SE, Parkinson JA. 1989. Nutrient elements. In: Allen SE (eds) Chemical 609 analysis of ecological materials, 2nd Edition, Blackwell Scientific, Oxford, pp 81-159.

610 Handa IT, Aerts R, Berendse F, Berg MP, Bruder A, Butenschoen O, ... Hättenschwiler S. 611 2014. Consequences of biodiversity loss for litter decomposition across 612 biomes. Nature 509:218-221. Doi: 10.1038/nature13247

613 Hättenschwiler S, Gasser P. 2005. Soil animals alter plant litter diversity effects on 614 decomposition. Proceedings of the National Academy of Sciences, 102:1519-1524. 615 https://doi.org/10.1073/pnas.0404977102

616 Hättenschwiler S, Tiunov AV, Scheu S. 2005. Biodiversity and litter decomposition in 617 terrestrial ecosystems. Annual Review of Ecology, Evolution and Systematics 36:191-218. 618 Doi: 10.1146/annurev.ecolsys.36.112904.151932 
Jabiol J, McKie BG, Bruder A, Bernadet C, Gessner MO, Chauvet E. 2013. Trophic complexity enhances ecosystem functioning in an aquatic detritus-based model system. Journal of Animal Ecology 82:1042-1051. Doi: 10.1111/1365-2656.12079

Jabiol J, Cornut J, Danger M, Jouffroy M, Elger A, Chauvet E. 2014. Litter identity mediates predator impacts on the functioning of an aquatic detritus-based food web. Oecologia, 176:225-235. Doi: 10.1007/s00442-014-2990-y

Jabiol J, Chauvet E. 2015. Biodiversity and litter decomposition: a case study in a Mediterranean stream. Freshwater Science 34:423-430. Doi: 10.1086/680094

Jenkins CC, Suberkropp K. 1995. The influence of water chemistry on the enzymatic degradation of leaves in streams. Freshwater Biology 33:245-253. Doi: 10.1111/j.1365-

$$
\text { 2427.1995.tb01165.x }
$$

Joyce P, Wotton RS. 2008. Shredder fecal pellets as stores of allochthonous organic matter in streams. Journal of the North American Benthological Society 27:521-528. Doi: 10.1899/07102.1

Kaspari M, Wright J, Yavitt J, Harms K, Garcia M, Santana M. 2008. Multiple nutrients limit litterfall and decomposition in a tropical forest. Ecology Letters 11:35-43. Doi: 10.1111/j.1461-0248.2007.01124.x

Kominoski JS, Pringle CM, Ball BA, Bradford MA, Coleman DC, Hall DB, Hunter MD. 2007. Nonadditive effects of leaf litter species diversity on breakdown dynamics in a detritus-based stream. Ecology 88:1167-1176. Doi: 10.1890/06-0674

Krauss GJ, Solé M, Krauss G, Schlosser D, Wesenberg D, Bärlocher F. 2011. Fungi in freshwaters: ecology, physiology and biochemical potential. FEMS microbiology reviews 35:620-651. Doi: 10.1111/j.1574-6976.2011.00266.x

Laughlin DC. 2011. Nitrification is linked to dominant leaf traits rather than functional diversity. Journal of Ecology 99:1091-1099. Doi: 10.1111/j.1365-2745.2011.01856.x 
644 Lecerf A, Dobson M, Dang CK, Chauvet E. 2005. Riparian plant species loss alters trophic 645 dynamics in detritus-based stream ecosystems. Oecologia 146:432-442. Doi: $646 \quad 10.1007 / \mathrm{s} 00442-005-0212-3$

647 Lecerf A, Risnoveanu G, Popescu C, Gessner MO, Chauvet E. 2007. Decomposition of diverse 648 litter mixtures in streams. Ecology 88:219-227. https://doi.org/10.1890/0012649 9658(2007)88[219:DODLMI $] 2.0 . \mathrm{CO} ; 2$

650 Lecerf A, Marie G, Kominoski JS, LeRoy CJ, Bernadet C, Swan CM. 2011. Incubation time, 651 functional litter diversity, and habitat characteristics predict litter-mixing effects on 652 decomposition. Ecology 92:160-169. Doi: 10.1890/10-0315.1

653 Leroy CJ, Marks JC. 2006. Litter quality, stream characteristics and litter diversity influence 654 decomposition rates and macroinvertebrates. Freshwater biology 51:605-617. Doi: 655 10.1111/j.1365-2427.2006.01512.x

656 Lummer D, Scheu S, Butenschoen O. 2012. Connecting litter quality, microbial community 657 and nitrogen transfer mechanisms in decomposing litter mixtures. Oikos 121:1649-1655. 658 Doi: $10.1111 /$ j.1600-0706.2011.20073.x

659 Makkonen M, Berg MP, Handa IT, Hättenschwiler S, van Ruijven J, van Bodegom PM, ... 660 Aerts R. 2012. Highly consistent effects of plant litter identity and functional traits on 661 decomposition across a latitudinal gradient. Ecology Letters 15:1033-1041. Doi: 662 10.1111/j.1461-0248.2012.01826.x

663 Mokany K, Ash J, Roxburgh S. 2008. Functional identity is more important than diversity in 664 influencing ecosystem processes in a temperate native grassland. Journal of Ecology 96:884665 893. Doi: 10.1111/j.1365-2745.2008.01395.x

666 National Research Council. 2005. Mineral Tolerance of Animals, 2nd ed. National Academic 667 Press, Washington.

668 Petchey OL, Gaston KJ. 2006. Functional diversity: back to basics and looking forward. 
Ecology letters 9:741-758.doi: 10.1111/j.1461-0248.2006.00924.x

670 Piscart C, Genoel R, Dolédec S, Chauvet E, Marmonier P. 2009. Effects of intense agricultural 671 practices on heterotrophic processes in streams. Environmental Pollution 157:1011-1018. 672 Doi: $10.1016 /$ j.envpol.2008.10.010

673 Piscart C, Navel S, Maazouzi C, Montuelle B, Cornut J, Mermillod-Blondin F, Creuse des 674 Chatelliers M, Simon L, Marmonier P. 2011. Leaf litter recycling in benthic and hyporheic 675 layers in agricultural streams with different types of land use. Science of the Total Environment 409:4373-4380. Doi: 10.1016/j.scitotenv.2011.06.060

677 Presa Abos C, Lepori F, McKie BG, Malmqvist B. 2006. Aggregation among resource patches 678 can promote coexistence in stream-living shredders. Freshwater Biology 51:545-553. 679 https://doi.org/10.1111/j.1365-2427.2006.01509.x

680 Quested H, Eriksson O, Fortunel C, Garnier E. 2007 Plant traits relate to whole-community 681 litter quality and decomposition following land use change. Functional Ecology 21:1016682 1026. Doi: 10.1111/j.1365-2435.2007.01324.x

R Core Team. 2013. R: A Language and Environment for Statistical Computing. R Foundation 684 for Statistical Computing, Vienna, Austria.

685 Ritz K. 2006. Fungal roles in transport processes in soils. In MG Gadd eds, Fungi in 686 biogeochemical cycles. Cambridge University Press, Cambridge, UK, pp. 51-73.

687 Sanpera-Calbet I, Lecerf A, Chauvet E. 2009. Leaf diversity influences in-stream litter 688 decomposition through effects on shredders. Freshwater Biology 54:1671-1682. Doi: $689 \quad 10.1111 / \mathrm{j} .1365-2427.2009 .02216 . x$

690 Santonja M, Baldy V, Fernandez C, Balesdent J, Gauquelin T. 2015a. Potential shift in plant 691 communities with climate change in a Mediterranean Oak forest: consequence on nutrients 692 and secondary metabolites release during litter decomposition. Ecosystems 18:1253-1268. 693 Doi: $10.1007 / \mathrm{s} 10021-015-9896-3$ 
694 Santonja M, Fernandez C, Gauquelin T, Baldy V. 2015b. Climate change effects on litter 695 decomposition: intensive drought leads to a strong decrease of litter mixture interactions. 696 Plant and Soil 393:69-82. Doi: 10.1007/s11104-015-2471-z

697 Santonja M, Pellan L, Piscart C. 2018a. Macroinvertebrate identity mediates the effects of litter 698 quality and microbial conditioning on the leaf litter recycling in temperate streams. Ecology 699 and Evolution 8:2542-2553. Doi: 10.1002/ece3.3790

700 Santonja M, Foucault Q, Rancon A, Gauquelin T, Fernandez C, Baldy V, Mirleau P. 2018b. 701 Contrasting responses of bacterial and fungal communities to plant litter diversity in a 702 Mediterranean oak forest. Soil Biology and Biochemistry 125:27-36. Doi: $703 \quad 10.1016 /$ j.soilbio.2018.06.020

704 Santschi F, Gounand I, Harvey E, Altermatt F. 2018. Leaf litter diversity and structure of 705 microbial decomposer communities modulate litter decomposition in aquatic systems. $706 \quad$ Functional Ecology 32:522-532. Doi: 10.1111/1365-2435.12980

707 Schimel JP, Hättenschwiler S. 2007. Nitrogen transfer between decomposing leaves of different 708 N status. Soil Biology and Biochemistry 39:1428-1436. Doi: 10.1016/j.soilbio.2006.12.037 709 Schindler MH, Gessner MO. 2009. Functional leaf traits and biodiversity effects on litter 710 decomposition in a stream. Ecology 90:1641-1649. Doi: 10.1890/08-1597.1

711 Srivastava DS, Cardinale BJ, Downing AL, Duffy JE, Jouseau C, Sankaran M, Wright JP. 2009. 712 Diversity has stronger top-down than bottom-up effects on decomposition. Ecology 713 90:1073-1083. Doi: 10.1890/08-0439.1

714 Swan CM, Palmer MA. 2004. Leaf diversity alters litter breakdown in a piedmont stream. 715 Journal of the North America Benthological Society 23:15-28.

716 Swan CM, Palmer MA. 2006a. Composition of speciose leaf litter alters stream detritivore 717 growth, feeding activity and leaf breakdown. Oecologia 147:469-478. Doi: 10.1007/s00442$718 \quad 005-0297-8$ 
Swan CM, Palmer MA. 2006b. Preferential feeding by an aquatic consumer mediates nonadditive decomposition of speciose leaf litter. Oecologia 149:107-114. Doi: 10.1007/s00442-006-0436-x

722

Swan C M. 2011. Consumer presence and resource diversity independently induce stability of ecosystem function in a Piedmont stream. Ecosphere 2:136. Doi: 10.1890/ES11-00274.1

Swift MJ, Heal OW, Anderson JM. 1979. Decomposition in terrestrial ecosystems. Berkeley, University of California press.

Vannote RL, Minshall GW, Cummins KW, Sedell JR, Cushing CE. 1980. The river continuum concept. Canadian Journal of Fisheries and Aquatic Sciences 37:130-137. Doi: 10.1139/f80017

Villanueva VD, Albarino R, Canhoto C. 2012. Positive effect of shredders on microbial biomass and decomposition in stream microcosms. Freshwater Biology 57:2504-2513. Doi: $10.1111 /$ fwb. 12023

Vos VC, van Ruijven J, Berg MP, Peeters ET, Berendse F. 2013. Leaf litter quality drives litter mixing effects through complementary resource use among detritivores. Oecologia 173:269280. Doi: $10.1007 / \mathrm{s} 00442-012-2588-1$

Wallace JB, Eggert SL, Meyer JL, Webster JR. 1997. Multiple trophic levels of a forest stream linked to terrestrial litter inputs. Science 277:102-104. Doi: 10.1126/science.277.5322.102

Wardle DA, Bonner KI, Nicholson KS. 1997. Biodiversity and plant litter: Experimental evidence which does not support the view that enhanced species richness improves ecosystem function. Oikos 79:247-258. Doi: 10.2307/3546010

Wetzel RG. 1995. Death, detritus, and energy flow in aquatic ecosystems. Freshwater Biology 33:83-89. Doi: 10.1111/j.1365-2427.1995.tb00388.x 


\section{TABLES}

744

745 Table 1. Effects of litter quality (NPL vs. NRL), litter species identity (10 species), litterbag 746 mesh size (fine-mesh vs. coarse-mesh litterbags), and their interactions on litter decomposition 747 rate and microbial activity in the single-species litterbags. d.f. $=$ degrees of freedom, $\% \mathrm{SS}=$ 748 percentage of type III sums of squares. $F$-values and associated $P$-values (with the respective 749 symbols * for $P<0.05$, ** for $P<0.01$, and *** for $P<0.001)$ are indicated.

750

\begin{tabular}{|c|c|c|c|c|c|}
\hline & \multirow[b]{2}{*}{ d.f. } & \multicolumn{2}{|c|}{ Litter decomposition } & \multicolumn{2}{|c|}{ Microbial activity } \\
\hline & & $\% \mathrm{SS}$ & $F$-value & $\% \mathrm{SS}$ & $F$-value \\
\hline Litter quality (LQ) & 1 & 59.1 & $854.8 * * *$ & 60.0 & $239.7 * * *$ \\
\hline Litter species (LS) & 8 & 12.6 & $22.8^{* * *}$ & 11.3 & $5.6 * * *$ \\
\hline Mesh size (MS) & 1 & 15.8 & $228.9 * * *$ & 11.1 & $44.3 * * *$ \\
\hline $\mathrm{LQ} \times \mathrm{MS}$ & 1 & 6.6 & $95.9^{* * *}$ & 1.4 & $5.7 *$ \\
\hline $\mathrm{LS} \times \mathrm{MS}$ & 8 & 1.6 & $3.0 * *$ & 1.1 & 0.6 \\
\hline Residuals & 60 & 4.2 & & 15.0 & \\
\hline
\end{tabular}

751

752 
753 Table 2. Effects of litter quality mixing (NPL-NPL, NPL-NRL and NRL-NRL), litterbag mesh

754 size (fine-mesh $v s$. coarse-mesh litterbags), and their interactions i) on litter decomposition rate 755 and microbial activity and ii) on relative mixture effects (RME) on litter decomposition rate

756 (LD) and on microbial activity (MA). d.f. = degrees of freedom, \%SS = percentage of type III

757 sums of squares. $F$-values and associated $P$-values (with the respective symbols $*$ for $P<0.05$,

$758 \quad * *$ for $P<0.01$, and $* * *$ for $P<0.001)$ are indicated.

759

\begin{tabular}{|c|c|c|c|c|c|c|c|c|c|}
\hline & \multirow[b]{2}{*}{ d.f. } & \multicolumn{2}{|c|}{ Litter decomposition } & \multicolumn{2}{|c|}{ Microbial activity } & \multicolumn{2}{|c|}{ RME on LD } & \multicolumn{2}{|c|}{ RME on MA } \\
\hline & & $\% \mathrm{SS}$ & $F$-value & $\% \mathrm{SS}$ & $F$-value & $\% \mathrm{SS}$ & $F$-value & $\% \mathrm{SS}$ & $F$-value \\
\hline Litter quality (LQ) & 2 & 49.1 & $617.5 * * *$ & 55.5 & $506.2 * * *$ & 21.6 & $58.0 * * *$ & 19.7 & $51.9 * * *$ \\
\hline Mesh size (MS) & 1 & 30.8 & $776.2 * * *$ & 23.1 & $421.8 * * *$ & 11.5 & $61.5 * * *$ & 13.4 & $70.7 * * *$ \\
\hline $\mathrm{LQ} \times \mathrm{MS}$ & 2 & 6.0 & $75.3 * * *$ & 2.1 & $18.6 * * *$ & 0.8 & 2.3 & 0.0 & 0.1 \\
\hline Residuals & 354 & 14.1 & & 19.3 & & 66.0 & & 66.8 & \\
\hline
\end{tabular}


762 Table 3. Effects of community-weighted mean traits (CWM), functional trait dissimilarities

763 (FD), litterbag mesh size (fine-mesh vs. coarse-mesh litterbags), and their interactions i) on

764 litter decomposition rate and microbial activity and ii) on relative mixture effects (RME) on

765 litter decomposition (LD) and on microbial activity (MA). CWM1 and CWM2, and FD1 and

766 FD2 represented the two first components of the PCAs conducted using the CWM or the FD

767 values in Supplementary Fig. S2. d.f. = degrees of freedom, \%SS = percentage of type III sums

768 of squares. $F$-values and associated $P$-values (with the respective symbols $*$ for $P<0.05$, **

769 for $P<0.01$, and $* * *$ for $P<0.001)$ are indicated.

770

\begin{tabular}{|c|c|c|c|c|c|c|c|c|c|}
\hline & \multirow[b]{2}{*}{ d.f. } & \multicolumn{2}{|c|}{ Litter decomposition } & \multicolumn{2}{|c|}{ Microbial activity } & \multicolumn{2}{|c|}{ RME on LD } & \multicolumn{2}{|c|}{ RME on MA } \\
\hline & & $\% \mathrm{SS}$ & F-value & $\% \mathrm{SS}$ & F-value & $\% \mathrm{SS}$ & F-value & $\% \mathrm{SS}$ & F-value \\
\hline CWM1 & 1 & 48.8 & $2693.2 * * *$ & 55.1 & $1344.1 * * *$ & 15.4 & $81.8 * * *$ & 23.1 & $129.3 * * *$ \\
\hline CWM2 & 1 & 1.6 & $86.4 * * *$ & 1.6 & $38.1 * * *$ & 0.3 & 1.4 & 0.3 & 1.7 \\
\hline FD1 & 1 & 3.7 & $202.3 * * *$ & 1.8 & $43.2 * * *$ & 0.2 & 0.8 & 0.2 & 1.1 \\
\hline FD2 & 1 & 1.9 & $107.1 * * *$ & 1.4 & $33.9 * * *$ & 3.7 & $19.9 * * *$ & 0.5 & 2.9 \\
\hline Mesh size (MS) & 1 & 30.8 & $1704.0 * * *$ & 22.9 & $559.5 * * *$ & 11.5 & $60.8 * * *$ & 13.3 & $74.6 * * *$ \\
\hline $\mathrm{CWM} 1 \times \mathrm{MS}$ & 1 & 6.0 & $332.0 * * *$ & 1.9 & $46.5 * * *$ & 0.3 & 1.3 & 0.0 & 0.3 \\
\hline $\mathrm{CWM} 2 \times \mathrm{MS}$ & 1 & 0.1 & 3.4 & 0.3 & $7.1 * *$ & 0.7 & 3.6 & 0.1 & 0.3 \\
\hline $\mathrm{FD} 1 \times \mathrm{MS}$ & 1 & 0.7 & $40.1 * * *$ & 0.7 & $17.5 * * *$ & 0.4 & 2.0 & 0.2 & 1.2 \\
\hline $\mathrm{FD} 2 \times \mathrm{MS}$ & 1 & 0.1 & $5.3 *$ & 0.1 & 2.7 & 1.6 & $8.3 * *$ & 0.0 & 0.2 \\
\hline Residuals & 350 & 6.3 & & 14.3 & & 66.0 & & 62.2 & \\
\hline
\end{tabular}

771 
773 Table 4. Relationships between CWM values of chemical element concentrations and relative 774 mixture effects (RME) on litter decomposition rate and on microbial activity in fine-mesh and 775 coarse-mesh litterbags. Adjusted $R^{2}$ and associated $P$-values $(* P<0.05, * * P<0.01$, *** $P<$ 776 0.001) are indicated.

777

\begin{tabular}{|c|c|c|c|c|c|c|c|c|}
\hline & $\mathrm{C}$ & $\mathrm{N}$ & $\mathrm{P}$ & $\mathrm{Ca}$ & $\mathrm{K}$ & $\mathrm{Mg}$ & $\mathrm{Na}$ & $\mathrm{S}$ \\
\hline \multicolumn{9}{|l|}{ RME on litter decomposition } \\
\hline Fine-mesh litterbags & $0.19 * *$ & $0.19 * *$ & $0.28 * * *$ & $0.26 * * *$ & $0.14 * *$ & $0.21 * *$ & $0.18 * *$ & $0.09 *$ \\
\hline Coarse-mesh litterbags & $0.17 * *$ & $0.12 *$ & $0.27 * * *$ & $0.35 * * *$ & $0.24 * * *$ & $0.30 * * *$ & $0.33 * * *$ & $0.15 * *$ \\
\hline \multicolumn{9}{|l|}{ RME on microbial activity } \\
\hline Fine-mesh litterbags & $0.12 *$ & 0.02 & $0.13 *$ & $0.27 * *$ & $0.26 * * *$ & $0.31 * * *$ & $0.27 * * *$ & $0.21 * * *$ \\
\hline Coarse-mesh litterbags & 0.07 & $0.16 * *$ & $0.27 * * *$ & $0.41 * * *$ & $0.30 * * *$ & $0.43 * * *$ & $0.16 * *$ & $0.16 * *$ \\
\hline
\end{tabular}

778 
782 Fig. 1. (a) Hypothetical relationship between the different categories of litter mixtures and the

783 litter decomposition rate of these litter mixtures. According to the mass-ratio hypothesis, the

784 decomposition rate increases with the increase in CWM values in nutrient concentration within

785 a litter mixture. (b) Hypothetical relationship between the different categories of litter mixtures

786 and the intensity of litter diversity effects occurring in these litter mixtures. According to the

787 niche complementary hypothesis, the intensity of litter diversity effects increases with the

788 increase in FD values in nutrient concentration, which would be shown by an increase in litter

789 decomposition rate in the present study. More precisely, this increase in decomposition rate,

790 due to synergistic effects between the two litters in mixtures, will be higher in litter mixtures

791 exhibiting intermediate nutrient concentration compared to litter mixtures exhibiting low or

792 high nutrient concentrations (Fig. 1a). NPL = nutrient-poor litter, NRL = nutrient-rich litter.

793 For both relationships, red dotted lines illustrate hypothetical increases in both litter

794 decomposition rate and litter diversity effects mediated by macroinvertebrate presence.

795

(a)

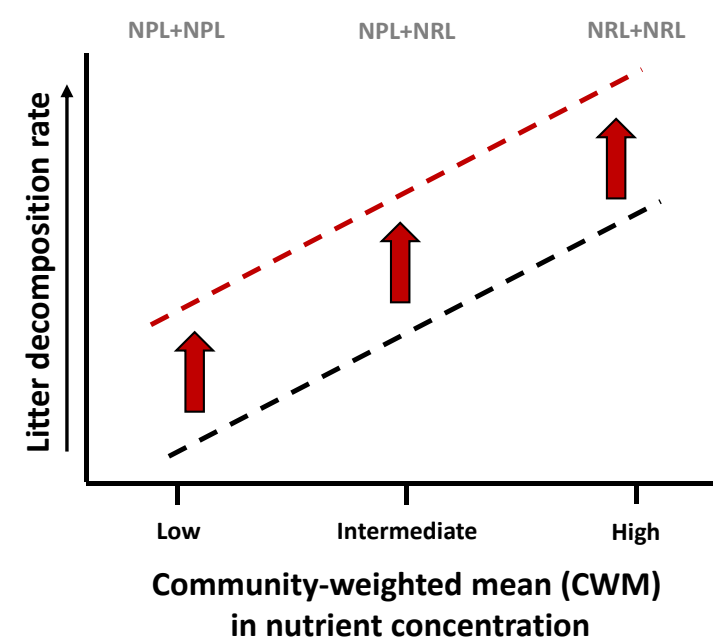

796 (b) Litter mixtures

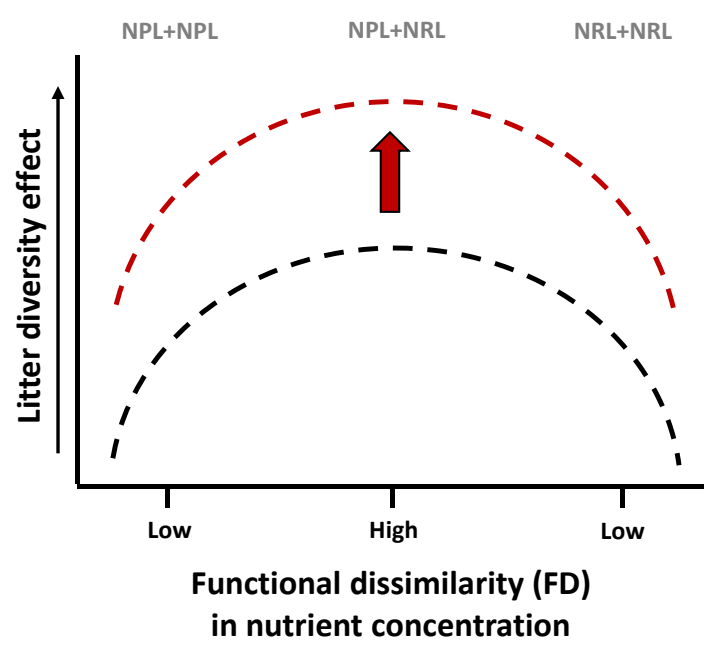


798 Fig. 2. Principal component analysis (PCA) based on the chemical element concentrations of 799 the 10 litter species. Variance explained by each principal component and associated 800 eigenvalues are shown in brackets.

801

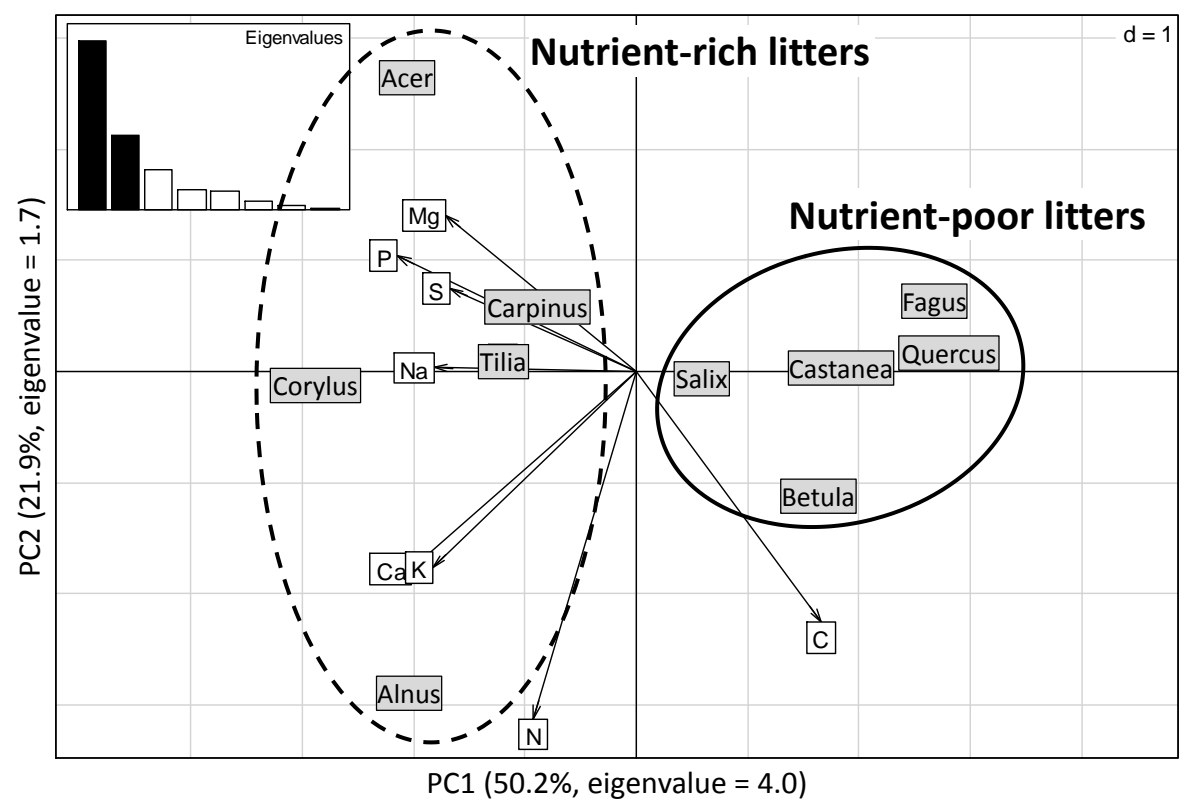

802 
804 Fig. 3. Litter decomposition rate (a) and microbial activity (b) in the single-species litterbags 805 according to litter quality (nutrient-poor litter [NPL] vs. nutrient-rich litter [NRL]) and to 806 litterbag mesh size (fine-mesh vs. coarse mesh litterbags). Each bar represents the mean value $807 \pm \mathrm{SE} ; \mathrm{n}=20$. The litter decomposition rate is indicated in percent mass loss relative to the initial 808 mass. The microbial activity is expressed as $\mu \mathrm{g} \mathrm{C}-\mathrm{CO}_{2}$ production per $\mathrm{h}$ and per $\mathrm{g}$ of litter. 809
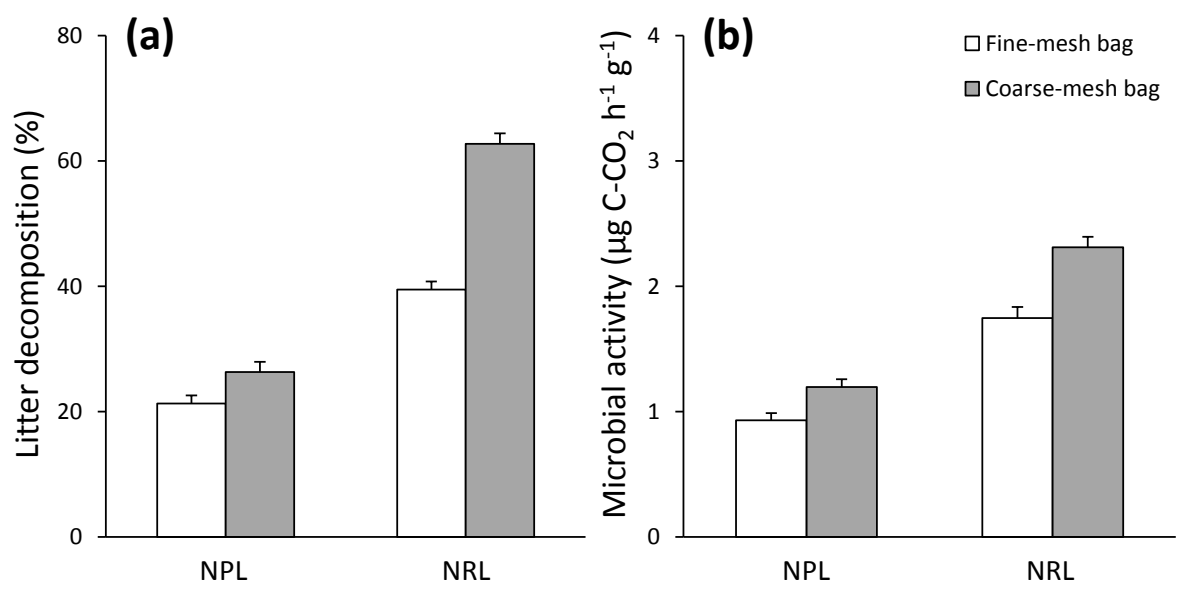
812 Fig. 4. Litter decomposition rate (a, b) and microbial activity (c, d) according to litter quality

813 mixing (a, c) and to litterbag mesh size (b, d). Each bar represents the mean value \pm SE. NPL

$814=$ nutrient-poor litter, NRL = nutrient-rich litter, FMB $=$ fine-mesh litterbag, $\mathrm{CMB}=$ coarse-

815 mesh litterbag. Different letters denote significant differences between treatments with $\mathrm{a}<\mathrm{b}<$

816 c.

817
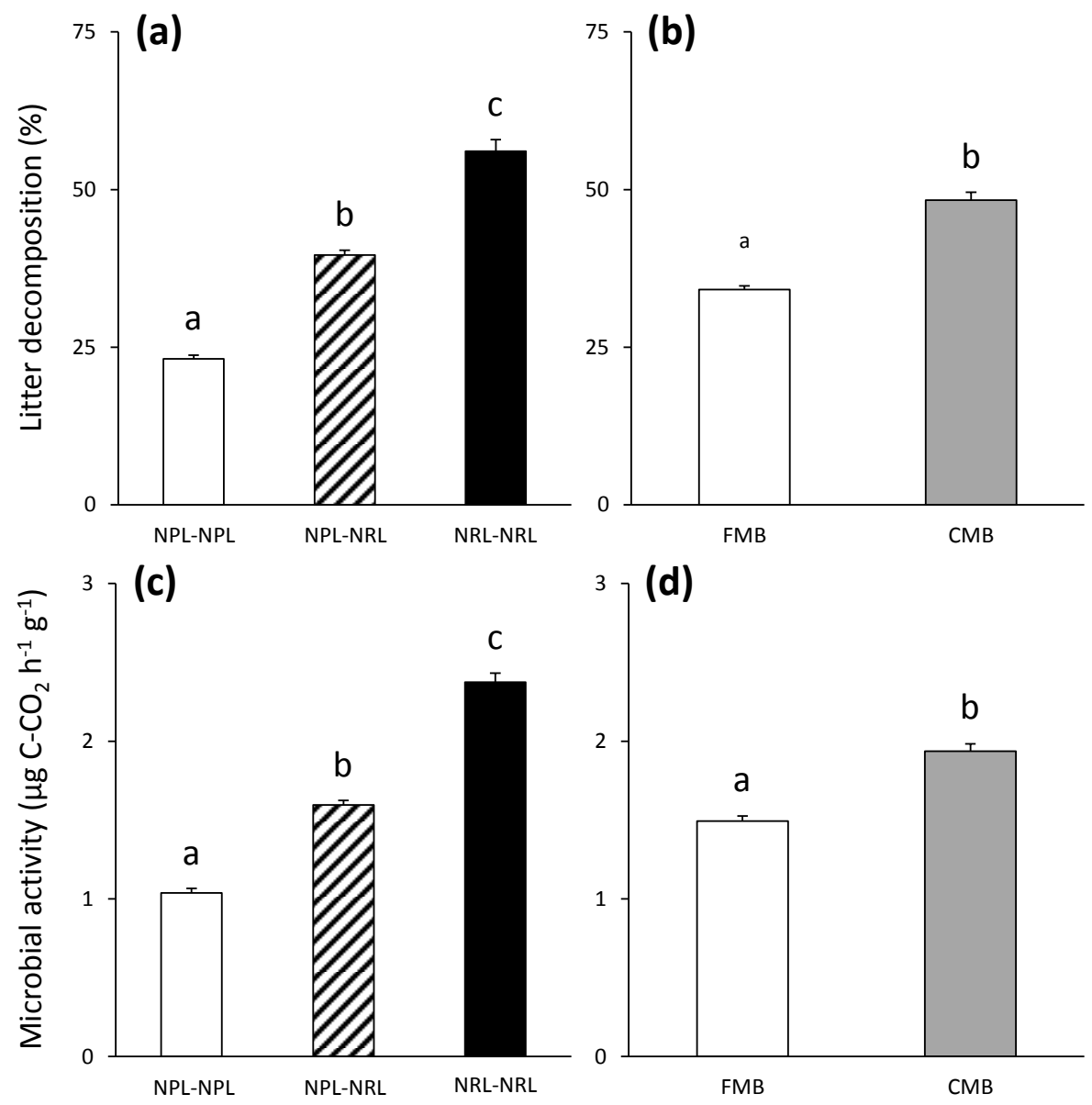

818 
820 Fig. 5. Relative mixture effects (RME) on litter decomposition rate (a,b) and on microbial

821 activity (c, d) according to litter quality mixing (a, c) and to litterbag mesh size (b, d). Each bar 822 represents the mean value $\pm \mathrm{SE} . \mathrm{NPL}=$ nutrient-poor litter, $\mathrm{NRL}=$ nutrient-rich litter, $\mathrm{FMB}=$ 823 fine-mesh litterbag, $\mathrm{CMB}=$ coarse-mesh litterbag. The RME on litter decomposition rate and

824 on microbial activity are indicated as the relative difference between the observed and the 825 expected values from the respective single litter species treatments. Different letters denote 826 significant differences between treatments with $\mathrm{a}<\mathrm{b}<\mathrm{c}$.

827

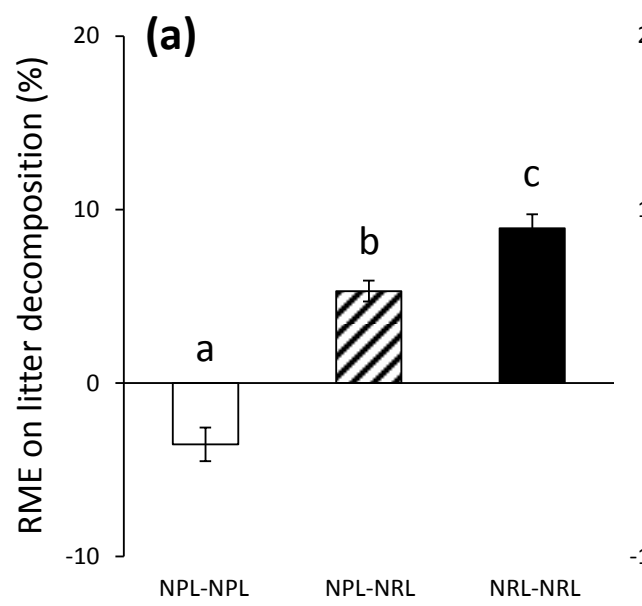

(b)

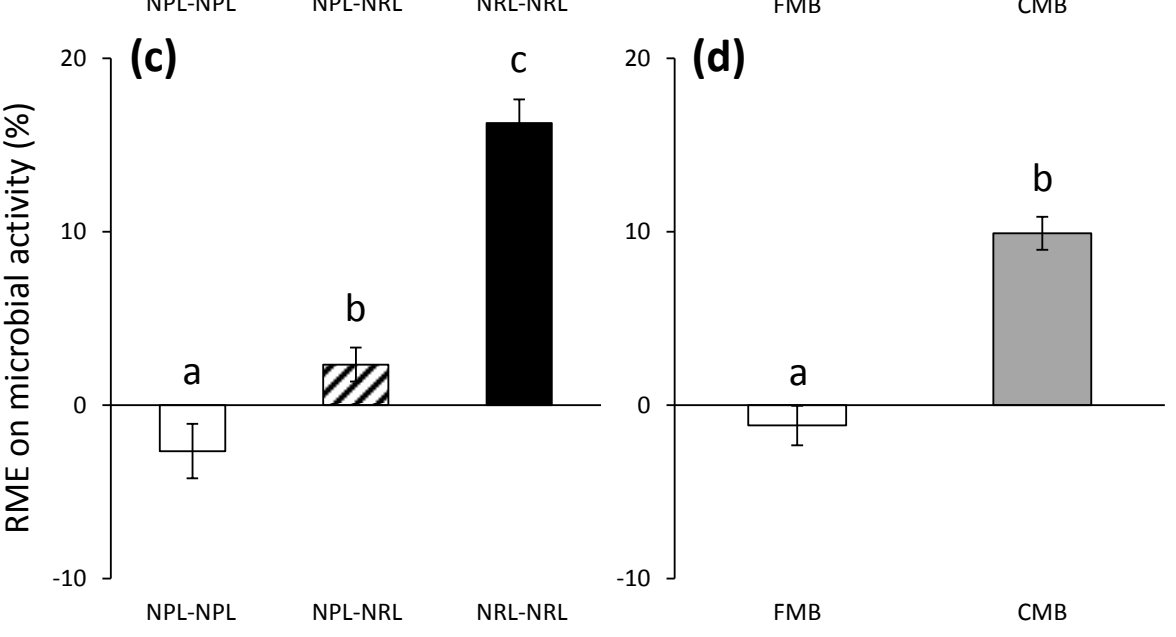


830 Fig. 6. Relative mixture effects (RME) on litter decomposition rate (panels a, b, c and d) and 831 on microbial activity (panels e, $\mathrm{f}, \mathrm{g}$ and $\mathrm{h}$ ) as a function of community weighted mean traits 832 (CWM1 and CWM2 from the PCA using the CWM values, Supplementary Fig. S2a) and 833 functional trait dissimilarities (FD1 and FD2 from the PCA using the FD values, Supplementary

834 Fig. S2b) in fine-mesh (white symbol) and coarse-mesh (grey symbol) litterbags. The RME on 835 litter decomposition rate and on microbial activity are indicated as the relative difference 836 between the observed and the expected values from the respective single litter species 837 treatments. Significant relationships are indicated with dotted (fine-mesh litterbags) or grey 838 (coarse-mesh litterbags) lines.

839
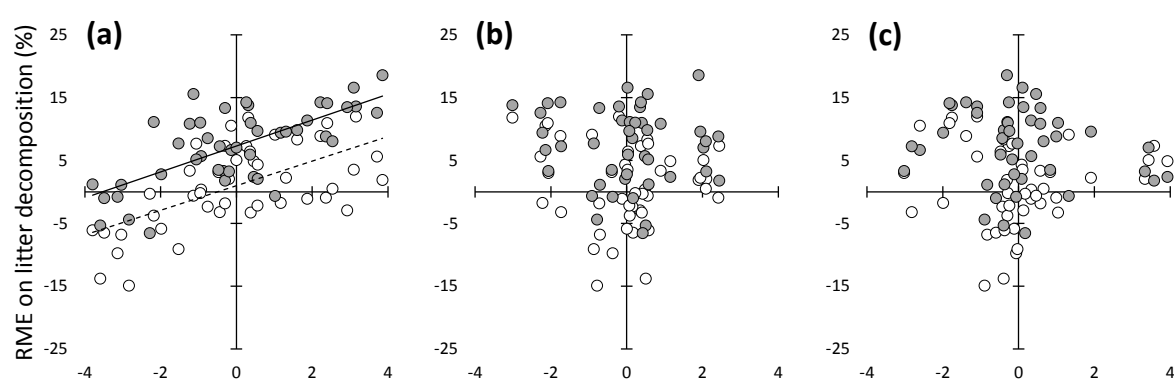

25 (d)
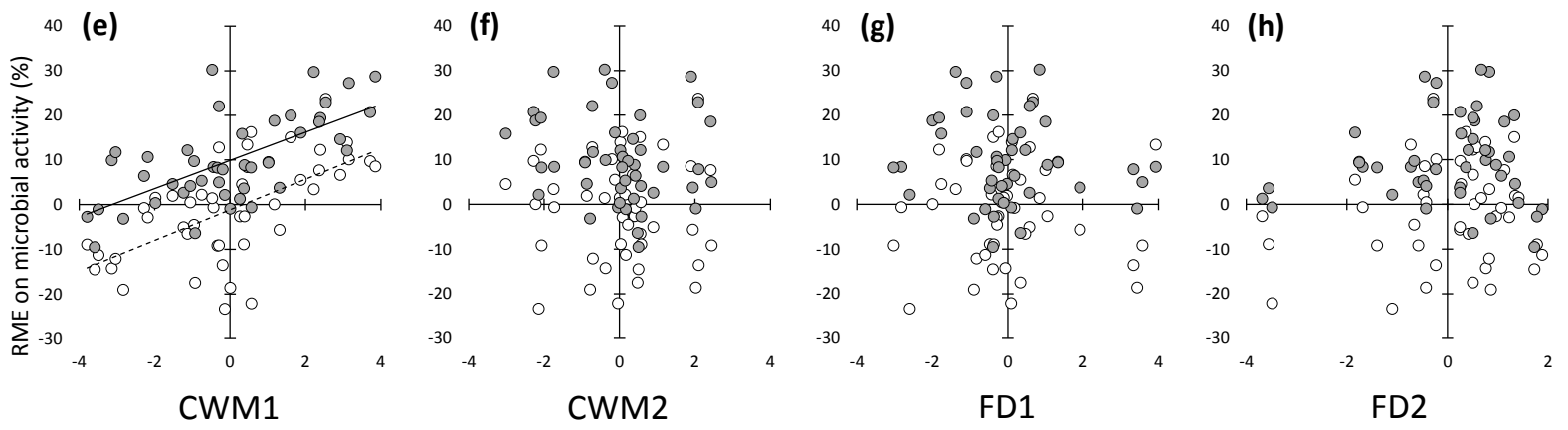

840 